\title{
A Matter of Justice, Human Rights, and New Ways of Thinking About Work
}

\author{
Roberto Covolo Bortoli \\ Technology College of São Paulo (FATEC-SP), São Paulo, Brazil
}

\begin{abstract}
This study deals with the employees' participation in the management of a company and the protection for economically employee. The workers are first citizens, human beings looking for the fulfilment of human rights and justice. There is a legal provision in the Brazilian Constitution about the participation in a company's management, which becomes more important as there is no labour union freedom in Brazil. The participation in the management is analysed within the social function concept of the company and its value chain. The aim is to investigate if the employees' participation in a company's management can enable profit, competitiveness, efficiency, and quality, without putting down the employees’ personal satisfaction, self-realization, self-esteem, projection, and motivation. This is an attempt to explain that it is not about converting the property into a patrimony of humanity, but only to subordinate private property to the community's interests, inside a vision of giving to each one what belongs to them. A company cannot exercise its right contrary to the interests and expectations of present and future generations. Disregarding the human rights, over-consuming resources and failing to implement economic improvements that benefit the community, since the private wealth accumulation cannot oppose to the common profit.
\end{abstract}

Keywords: participation, management, company

The employees' participation in the management of the company is foreseen by the Federal Constitution of 1988 (Art. $\left.7^{\circ}, \mathrm{XI}\right)$.

It is important to define the participation of the employees' participation in the management of the company.

The method can be from collaboration until participation in the company's management.

The company's management puts the property question in evidence.

The company and the profit are the property of the owner. So, it cannot be shared with the employees.

However, the same Brazilian Constitution's article which deals with the participation in the company's management, deals with the profit participation.

In Brazil, the company can negotiate with the union, a way of participation in the profits. And, this really happens, but not in all companies.

This profit participation is not mandatory, but only indicates a direction.

Corresponding author: Roberto Covolo Bortoli, MA, Ph.D. candidate of the Faculty of Law São Francisco, University of São Paulo (USP), professor, Technology College of São Paulo (FATEC-SP), maintained by the State Center of Technological Education, Paula Souza, and associated with São Paulo State University, Julio de Mesquita Filho (UNESP); research fields: human rights, labour law, environmental law and ethic. E-mail: rcb2004@gmail.com; roberto@covolo-bortoli-advogado.com. 
Shareholders and employees contribute with money and labour to the success of the company, but the law treats them differently.

While the employees cannot manage a company for their own interest, the shareholders can.

How to overcome this deadlock? And this is not a question of ideology, but of justice.

Before being a citizen, the employee is a human being searching for effectuation of the human rights and justice.

There is a provision in the Brazilian Constitution about participation in the company's management, which becomes more important, as there is not any freedom of union in Brazil, within work areas.

The employees do not freely choose the union and, therefore, can never organize themselves as they might like to. Hence, there is no democracy.

By the Brazilian law, there can be only one union by professional category by municipal area (Art. $8^{\circ}$, II of the Federal Constitution).

If the union organization of the interest of the employees has this limitation, to associations, the employees' participation in the management of the company will not happen if you think about the limitation of the union.

There are many benefits in the employees' participation in the management of the company.

The participation in the management of the company is spontaneous.

The management problems can be solved in a quickier way, since the employees are involved.

The answer to the management problem is specific and not generic.

The corrections of errors by management are easier.

The knowledge of the problem is immediate, because there is not a long command chain.

The employees become more satisfied through participation in the management. The employees are valued. There is satisfaction and recognition in the workplace.

And the economically weak employees feel more protected.

\section{The Employees' Participation in the Management, Within the Social Function Concept of the Company and Its Value Chain}

In the Article $5^{\circ}$, XXIII, of the Federal Constitution, it is established that the property must have a social function.

The company's owner must respect the collective interests.

To respect the collective interests, it must be aware of what the collective wants and be aware of what he wants.

The internal processes of the organization and the way that they deal with external audiences can be divided into smaller processes. So, it is possible to verify whether the strategy is aligned with the result. This is what can be called, briefly, the value chain as proposed by Michael Eugene Porter.

Returning to the beginning, what is the real function of the company? And how to respect the human rights, if they are not a goal to be achieved by the companies?

\section{The Millennium Development Goals of the United Nations}

The Millennium Development Goals of the United Nations (UN) to eradicate extreme poverty were partially achieved. More than one billion people have been lifted from the extreme poverty according to the UN report of July 6 of 2015. 
But in a dubious economic environment, such as in Brazil and others part of the world, new ways of work can contribute even more to eradicate poverty.

Quick and effective changes are needed in institutions and laws that are not solving the problems of today's world.

We must look for new ways to work in order to benefit the employees and the employer, attending, consciously, their aspirations for a good quality of, and productive, life.

To what extent can work in the world today be capable of developing the consciousness of the human being, without alienating them even more?

We have to align, again, the work and its purpose.

Is it the purpose of work only to survive, or should work be a source of personal satisfaction, providing consciousness development?

We believe that work should be a source of personal satisfaction, providing consciousness development. Therefore, new bases must be launched to reach this supreme goal, for the human being's happiness.

\section{Aligning Common Goals: The Company and Its Employees}

It is possible that employee participation in the management of the company, allows the profit, the competitiveness, efficiency, and quality, without sacrificing the personal satisfaction, self-realization, recognition, projection, and motivation of the employee.

The employee can participate in the management of the company and in its profit.

As we saw, it is not about converting the property into an inheritance of humanity, but only to subordinate private property to the community's interests, inside a vision of giving to each one what belongs to them.

The company cannot exercise its right contrary to the interests and expectations of the present and future generations, causing damages to human rights, over consumption of resources and no-implementation of economic improvements that benefit the collective, since the private accumulation of wealth, cannot be opposite to the collective profit.

We have considered the particularly vulnerable workers' situation such as women, minors, HIV-positive people, disabled, elderly, and people with different sexual orientations.

Even with the gradual change to and implementation of the legislation regarding improving the protection of these especially vulnerable people and the companies that incorporate these changes, allow people to understand that they must be especially protected.

After all, should only some human beings be protected? No, obviously not. Human beings are made in the image and resemblance of God (Imago Dei) that is the base to the recognition of human rights.

\section{The Company's Responsibility}

Companies have a responsibility to try to resolve moral global problems that the humanity faces, because companies cannot survive in a world in which everyone loses.

Each human being has the same right, whether they are the company's owners or employees.

Human rights cannot be counteracted, by the argument of profit.

Each entity, independently of its condition in society, deserves respect.

At this point, it is important to pass on the message of the movie: The Corporation.

The film is based on the book The Corporation: The Pathological Pursuit of Profit and Power by Joel Bakan. 
Here is an interesting passage taken from the movie:

Drawing the metaphor of the early attempts to fly.

The man going off of a very high cliff in his airplane with the wings flapping and the guys flapping the wings and the wind is in his face and this poor fool think he is flying but in fact, he is in freefall and he just does not know it yet because the ground is so far away.

But of course the craft is doomed to crash.

That is the way our civilization is the very high cliff represents the virtually unlimited resources we seem to have when we began this journey.

The craft is not flying because it is not built according to the laws of aerodynamics and is subject to the law of gravity.

Civilization is not flying because it is not built according to the laws of aerodynamics for civilizations that would fly.

And of course the ground is still a long way away but some people have seen that ground rushing up sooner than the rest of us have.

The visionaries have seen it and have told us its coming.

There is not a single scientific peer reviewed paper published in the last 25 years that would contradict this scenario.

Every living system of Earth is in decline, every life support system of earth is in decline, and these together constitute the biosphere.

The biosphere that supports and nurtures all of life not just our life but perhaps 30 million other species, that share this planet with us.

The typical company of the 20th century extractive wasteful abusive linear in all of its processes taking from the Earth making wasting sending its products back to the biosphere waste to a landfill...

Parameters already in use are no longer useful to society. We must search for new parameters.

\section{Education and the Future}

Brazil has the necessity to think about a quicker, more extensive, and substantial education.

A Brazilian university takes around five years to graduate, then three more years for a master's degree and five years for a doctorate.

From the beginning to the end of the university, probably, the student will have to deal with two or three different kinds of computer programs.

The changes are so fast that not even the education institution will have time to upgrade itself.

It is better to focus the education, concentrating on the essential values, thereby reducing the graduation time.

The essential values must permit the society to develop. The education must be aimed to the development of the consciousness, social solidarity and show that being is more than having, among others values.

The technology colleges (FATECs) have introduced courses for graduation in three years.

They are an example of success, since there are 64 technology colleges (FATECs), distributed across São Paulo state.

The FATECS have more than 73,000 students, with 71 technology graduation courses and distance education. 
A more focused structure and a faster graduation allow a speedier entrance in the labor market.

The waiting time to work is reduced.

Of course that many aspects of the education will by necessity need to be reviewed. The institutions will have to change to adopt the new necessities.

\section{Conclusions}

We must encourage people to participate in the company's management.

In moments of crisis, we have to focus on the essential.

The company problems cannot be solved by a few people. Neither can the humanity problems. It is necessary that we all are conscious of this.

The consciousness does not germinate alone, it needs stimulation. The education is the biggest stimulus for growth and change.

The education and work must look for the consciousness development.

\section{References}

Craig, J. D. R., \& Lynk, S. M. (Eds.). (2006). Globalization and the future of labour law. United Kingdom: Cambridge University Press.

Davidov, G., \& Langille, B. (Eds.). (2006). Boundaries and frontiers of labour law goals and means in the regulation of work. International Institute for Labour Studies, Oxford and Portland, Oregon.

Davies, A. C. L. (2009). Perspectives on labour law (2nd ed.). United Kingdom: Cambridge University Press.

Kauffman, S. (1993). The origins of order. New York: Oxford University Press.

Martins, S. P. (2008). Direitos fundamentais trabalhistas (Fundamental labour rights) (p. 5). São Paulo: Atlas.

Pereira, A. Jr., \& Pereira, M. A. O. (2010). Theory of self-organization: An introduction and possible application in health sciences. Retrieved from http://www.ibb.unesp.br/Home/Departamentos/Educacao/Simbio-Logias/teoria_da_autoorganizacao_uma_introducao.pdf

Porter, M. E. (1985). Competitive advantage (pp. 11-15). New York: The Free Press. 